\title{
Engineering Annual Summary 1996
}
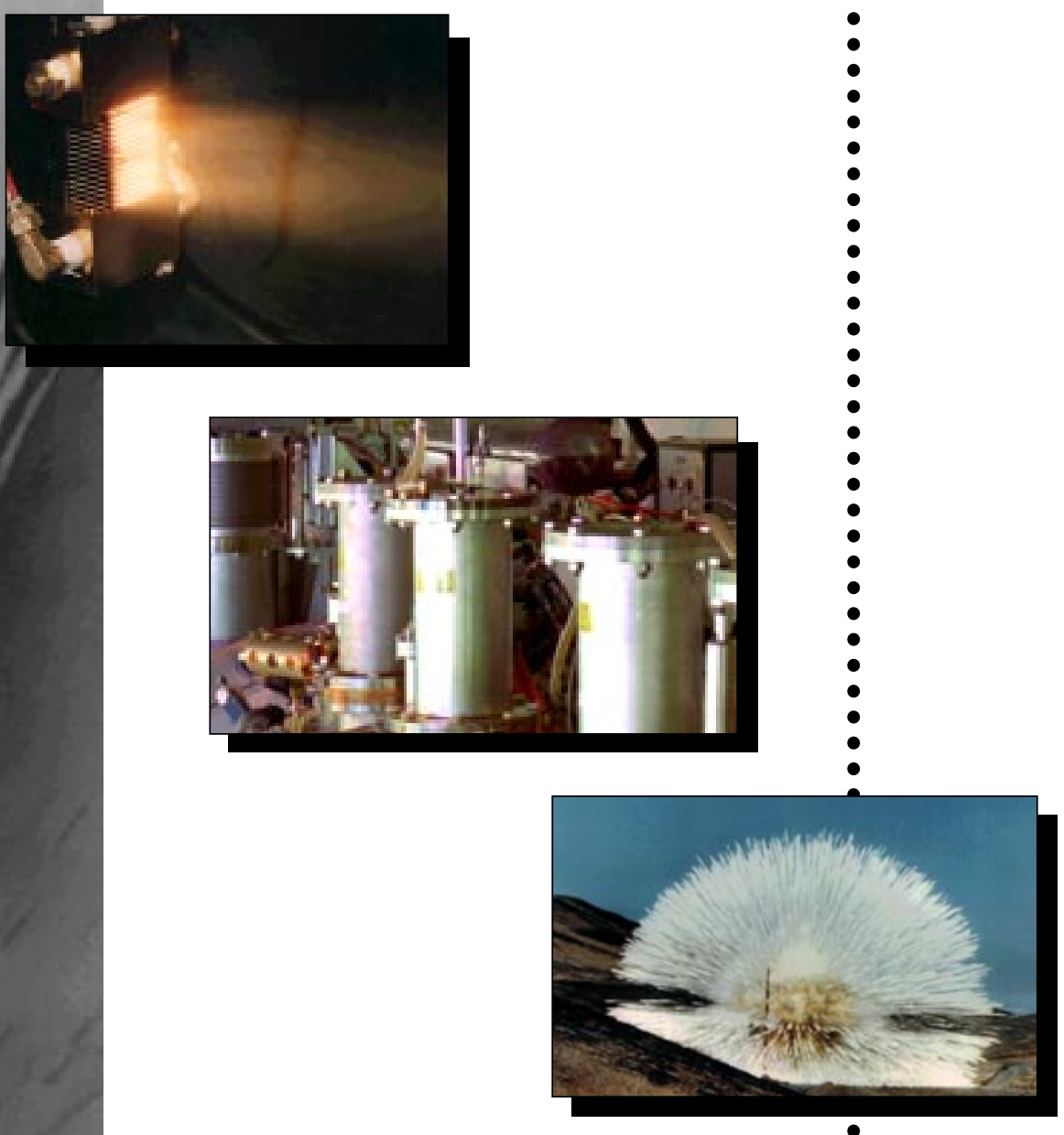

:

Lawrence Livermore National Laboratory 
This report has been reproduced directly from the best available copy.

Available to DOE and DOE contractors from the

Office of Scientific and Technical Information P. O. Box 62, Oak Ridge, TN 37831

Prices available from (615) 576-8401, FTS 626-8401

Available to be public from the

National Technical Information Service

U. S. Department of Commerce

5285 Port Royal Rd.

Springfield, VA 22161

\section{Disclaimer}

This document was prepared as an account of work sponsored by an agency of the United States Government. Neither the United States Government nor the University of California nor any of their employees makes any warranty, express or implied, or assumes any legal liability or responsibility for the accuracy, completeness, or usefulness of any information, apparatus, product, or process disclosed, or represents that its use would not infringe privately owned rights. Reference herein to any specific commercial products, process, or service by trade name, trademark, manufacturer, or otherwise, does not necessarily constitute or imply its endorsement, recommendation, or favoring by the United States Government or the University of California. The views and opinions of authors expressed herein do not necessarily state or reflect those of the United States Government or the University of California and shall not be used for advertising or product endorsement purposes.

Work performed under the auspices of the U.S. Department of Energy by Lawrence Livermore National Laboratory under Contract W-7405-ENG-48. 


\title{
Engineering Annual Summary 1996
}

\author{
Spiros Dimolitsas \\ Associate Director for Engineering \\ Lawrence Livermore National Laboratory
}

April 30, 1997

Engineering Annual Summary FY96 


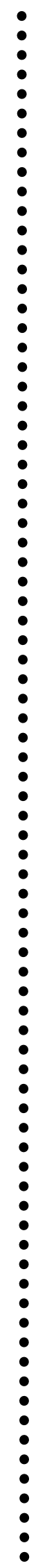

Engineering Annual Summary FY96 


\title{
Contents
}
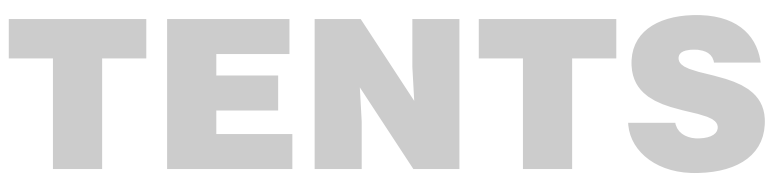

\section{(1) Associate Director's Message \\ 3 Overview of LLNL \\ 3 LLNL Funding and Workforce}

\section{(4) Engineering Overview}

\author{
4 Mission \\ 4 Organization \\ $5 \quad$ Engineering Facilities
}

(5) Engineering Funding and Workforce
$5 \quad$ Funding
6 Workforce

\section{(7) FY96 Significant Accomplishments}

7 Business Accomplishments

7 The Engineering Strategic Plan

7 Reduction of Overhead Rates and Distributed Costs

7 Consolidated Facilities

8 Workforce Restructuring of Workforce Transfers

8 Commenced Restructuring of Core Technologies

\section{Technical Accomplishments}

$9 \quad$ National Ignition Facility (NIF) Final Title I Design Review

9 Laser Cutting

10 Flash X-ray (FXR)

10 Microactuated Mirror for Interferometry

10 Polymerase Chain Reaction (PCR)

11 Big Explosives Experimental Facility (BEEF)

11 National Transparent Optical Network (NTON)

\section{Honors and Awards}

121996 Award for Excellence in Technology Transfer

12 Director's Performance Awards

131996 R\&D 100 Awards

\section{(14) Challenges for the Future}

\section{(15) Appendix}

16 Engineering Costs by Budget Type

16 Engineering Five-Year Costing Trend

17 Engineering Department Organization Chart

18 LLNL Staffing and Education Levels

19 Engineering Staffing Profile

19 Engineering Workforce Changes

20 Engineering Facility Changes

\section{Cover} photos:

Top: Microchannel cooler

Center: FXR upgrade project Bottom: Open air hydrodynamic test at Site 300 


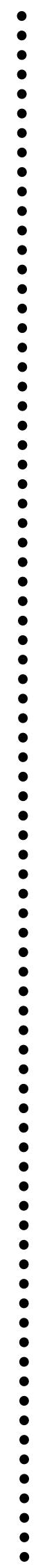

Engineering Annual Summary FY96 


\section{Associate Director's Message}

Fiscal year 1996 has been a year of significant change for the Lawrence Livermore National Laboratory (LLNL) in general and for Engineering in particular. Among these changes, the Laboratory's national security mission was better defined, the stockpile stewardship program objectives became crisper, LLNL's investment in high-performance computing was re-emphasized with the procurement of a $\$ 100$ million supercomputer for the Laboratory's Accelerated Strategic Computing Initiative (ASCI) program, two major Laser programs (the National Ignition Facility and Atomic Vapor Laser Isotope Separation) expanded significantly, and DOE's human genome efforts moved to the next phase of development.

In the area of business operations, LLNL's Cost Cutting Initiative Program (CCIP) was completed and the Laboratory restructured its workforce using a Voluntary Separation Incentive Program (VSIP).

Engineering similarly also saw many technical and programmatic successes, as well as changes, starting with completion of its strategic plan, significant consolidation of its facilities, restructuring of its workforce, reduction of its overhead costs, substantial transfers of staff between programs, and finally my personal arrival at Livermore.

This report is the first opportunity to capture some of Engineering's FY96 activities and accomplishments in a succinct fashion, and to relate these to our strategic plan.

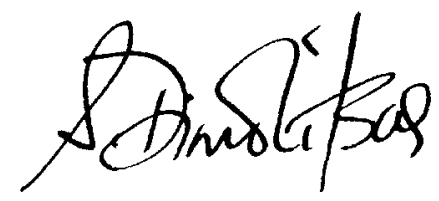

Spiros Dimolitsas

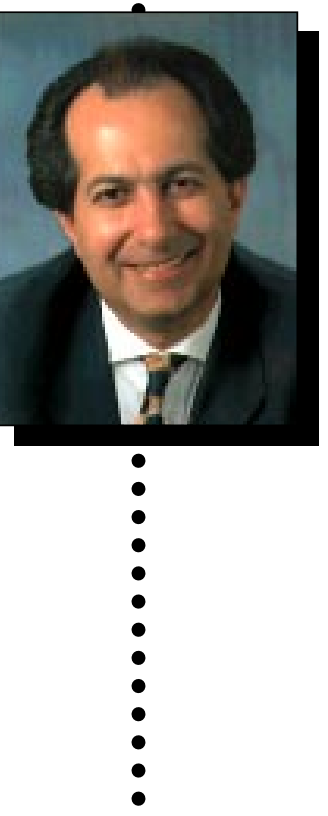




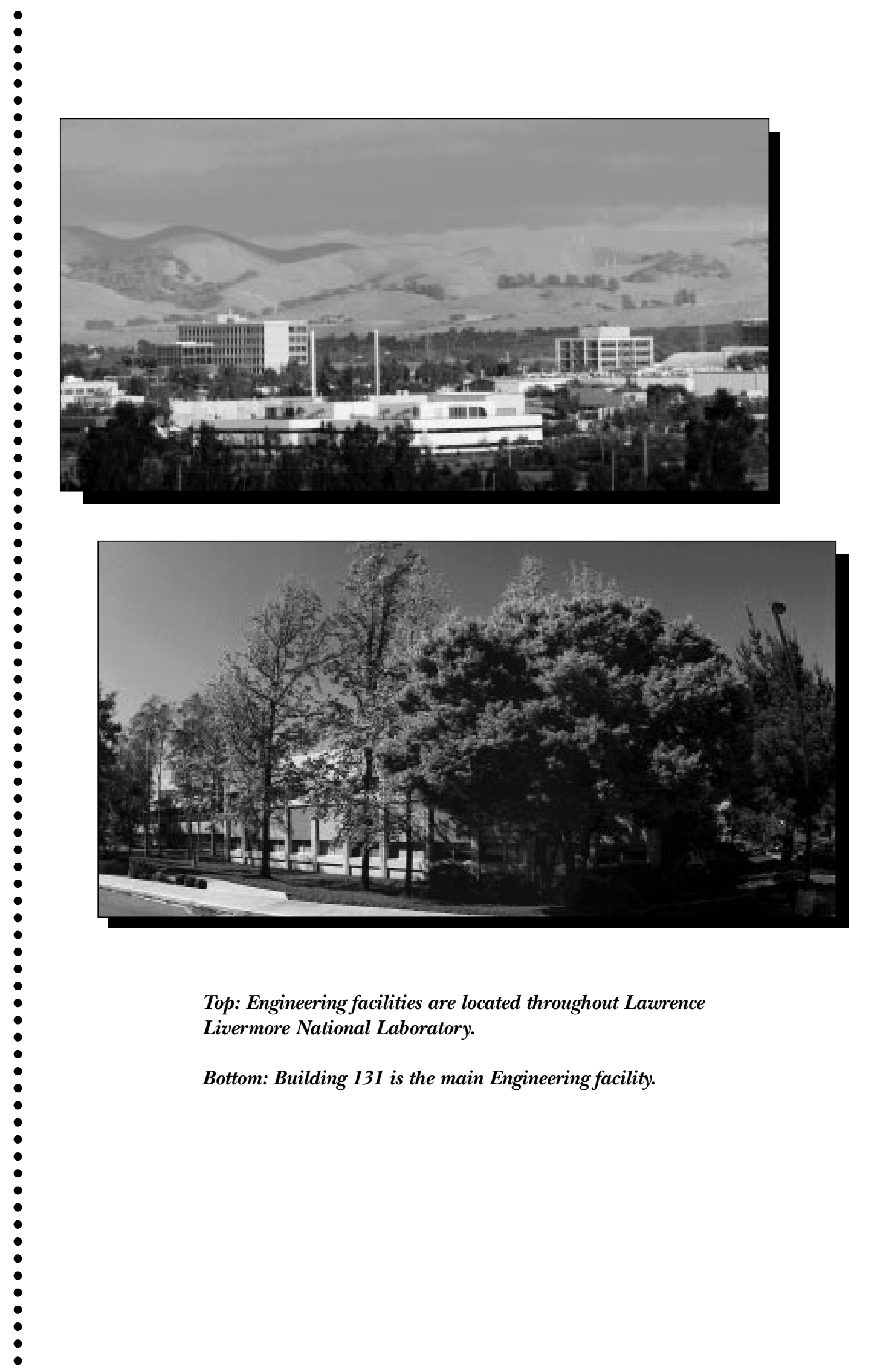




\section{Overview of LLNL}
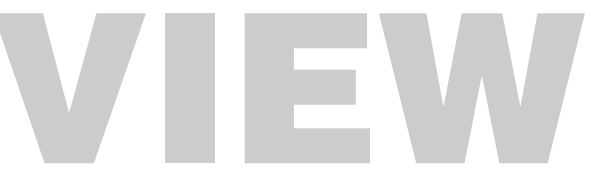

The Lawrence Livermore National Laboratory (LLNL) was established in 1952 to help ensure national security through the design, development, and stewardship of nuclear weapons. The Laboratory is a premier applied science national security laboratory. Its primary mission is to assure that the nation's nuclear weapons remain safe, secure and reliable, and to prevent the spread and use of nuclear weapons worldwide. This mission enables its programs in advanced defense technologies, energy, environment, biosciences, and basic sciences to apply Livermore's unique capabilities, and to enhance the competencies needed for its national security mission. The Laboratory serves as a resource for U.S. industry and government.

Central to the Laboratory's success are its diverse, highly talented and skilled workforce and its multibillion-dollar plant and research facilities. The University of California has managed the Laboratory since its inception under contract with the U.S. Department of Energy and its predecessors.

\section{LLNL Funding and Workforce}

The Laboratory's FY96 budget was only slightly larger than the FY95 budget-approximately $\$ 1$ billion. From this, $\$ 879$ million was devoted to operations and $\$ 132$ million to capital projects. (See Figure 1.)

On average, LLNL's staffing level in FY96 consisted of 7,326 employees and 649 contract (supplemental labor) employees. (See the LLNL Staffing and Education levels chart in the Appendix.) From these, 38\% were scientists and engineers, $37 \%$ technical and crafts personnel (tradespeople), and 25\% administrative and clerical. Among the scientific staff, $35 \%$ are engineers and $32 \%$ are physicists. The remaining $33 \%$ is made up of chemists, computer scientists, environmental scientists, metallurgists, etc.

Figure 1. LLNL Funding Profile (Actual Costs)

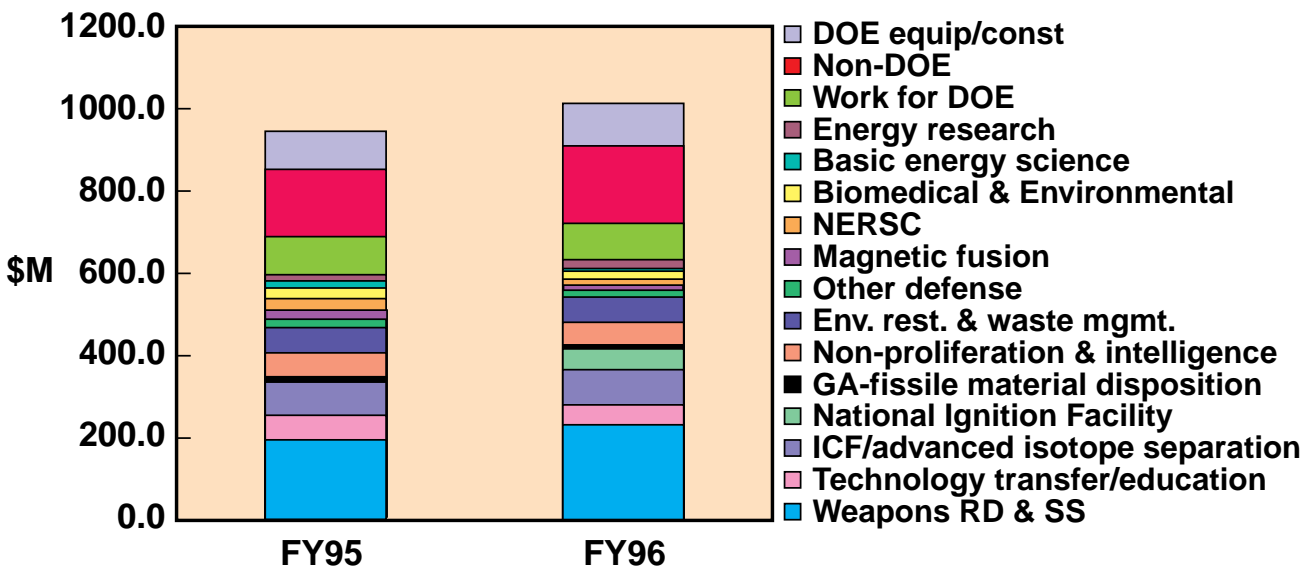


Figure 2. LLNL Five-Year Funding Trend

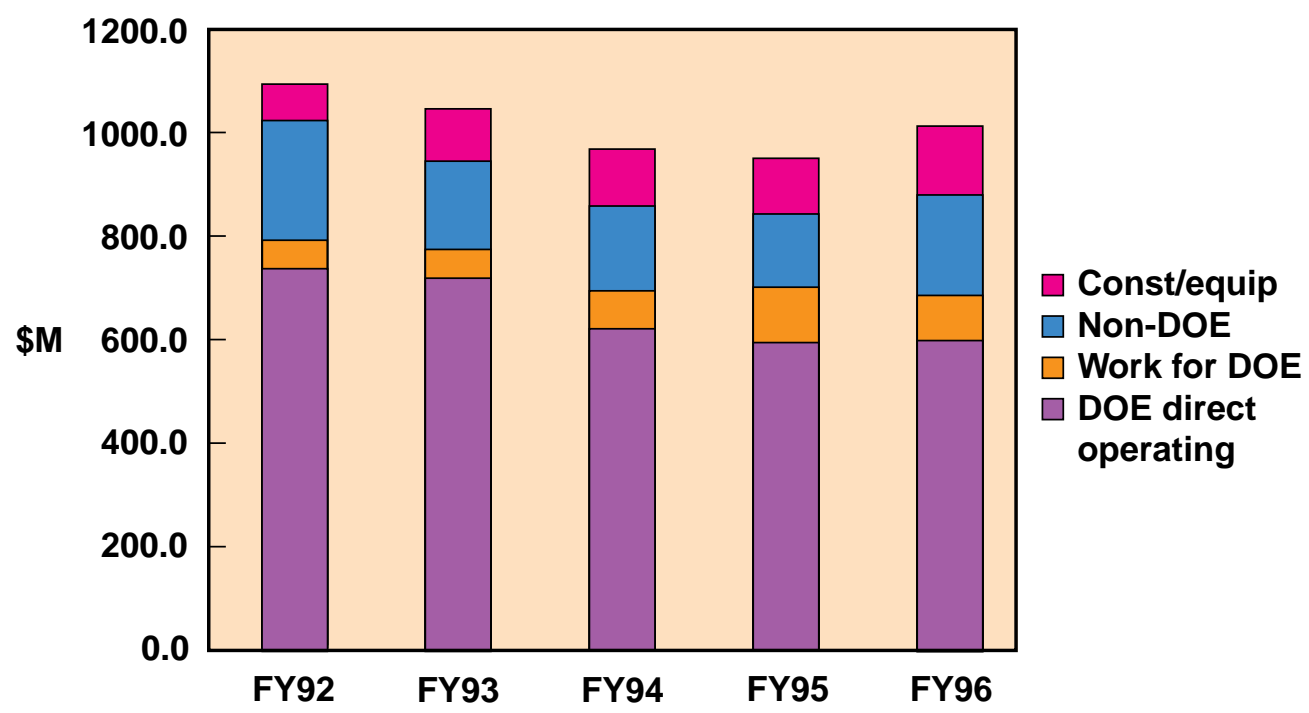

\section{Engineering Overview}

\section{Mission}

Engineering's mission is to make Livermore programs succeed by developing the people and cutting-edge technologies necessary to foster programmatic growth and future Laboratory success. Through these actions, Engineering provides unique, world-class engineering resources that enable Laboratory directorates to translate their objectives into physical deliverables on time, within budget, and to specifications.

In support of the variety of research programs at LLNL, Engineering conducts innovative research and development in the following core technologies: computational mechanics and electromagnetics; microelectronics modeling and fabrication; materials science and precision engineering; pulsed-power and microwave technology; nondestructive evaluation; and optical engineering. Through interdisciplinary teams from these areas, each project's specific engineering needs are met by nationally and internationally recognized engineers and scientists.

\section{Organization}

The Engineering Directorate is a multidisciplinary organization with expertise in many of the major engineering fields. Engineering is organized along two fundamental disciplines, mechanical engineering and electronics engineering. (An organization chart is in the Appendix.) Its wide-ranging 
capabilities are a direct outgrowth of Livermore's nuclear weapons work and the interdependence of weapons design, computational modeling, engineering, safety, and performance. The Directorate simulates engineering systems, improves systems designs, and tests the performance of these systems when they are built. Engineering manages numerous large and small-scale projects requiring complex interactions among many scientific disciplines. There are approximately 2,100 employees in Engineering, with 1,800 of them being typically matrixed to program directorates.

\section{Engineering Facilities}

Engineering owns and operates 35 facilities at the main LLNL site in Livermore. These facilities total 800,000 gross square feet, with $70 \%$ dedicated to working engineering laboratories, shops, and computer, equipment, and storage space, and $30 \%$ dedicated to office space. In addition, Engineering operates 59 buildings and magazines at Site 300, a 45-squaremile test site that LLNL manages near Tracy, California. (See the site map in the appendix.)

After the transfer of the High Explosives (HE) process facilities to the Chemistry \& Materials Science (C\&MS) directorate, Engineering will own a total of five buildings, one trailer, and 17 magazines and storage facilities at Site 300.

\section{Engineering Funding and WorkforceFunding}

Engineering’s $\$ 331.2$ million FY96 funding came from three sources: programmatic support, distributed costs, and direct funding.

-Programmatic support is derived from LLNL programs, which Engineering supports by matrixing approximately $80 \%$ of its personnel to those programs. In FY96, programmatic support accounted for $\$ 270$ million, or $81.5 \%$ of Engineering's funding. This funding is managed in the programs but pays for the wages of Engineering's matrixed personnel.

-Distributed costs are associated with: Organizational Personnel Costs (OPC) to fund activities such as personnel management, administration, recruitment, conferences and training, etc.; Organization Facilities Costs (OFC); recharges from Engineering Service Centers such as Manufacturing and Materials Engineering, Electronics Manufacturing and the Engineering Records Center; General and Administrative (G\&A) costs; and Program Management Costs (PMC). Distributed costs account ed for $\$ 56.4$ million, or $17 \%$ of Engineering's FY96 funding.

-Engineering's third funding source, direct funding, is for work done under contract for others, such as work for others (WFO) and work for DOE (WF/DOE) contracts. It also includes the Laboratory Directed Research and Development (LDRD) program. Direct funding accounted for $\$ 4.8$ million, or $1.5 \%$, of Engineering’s FY96 funding. 


\section{: Workforce}

As LLNL's largest directorate, Engineering provides support to every Laboratory program. Defense \& Nuclear Technologies (D\&NT) and Lasers were the two programs where significantly increased support was provided during FY96, as it can be seen from Figure 3.

In FY96, Engineering's full-time equivalent (FTE) workforce dropped by $9.2 \%$, with approximately half of this reduction due to the Voluntary Separation Incentive Program (VSIP).

Figure 3. Engineering Staffing Changes FY96

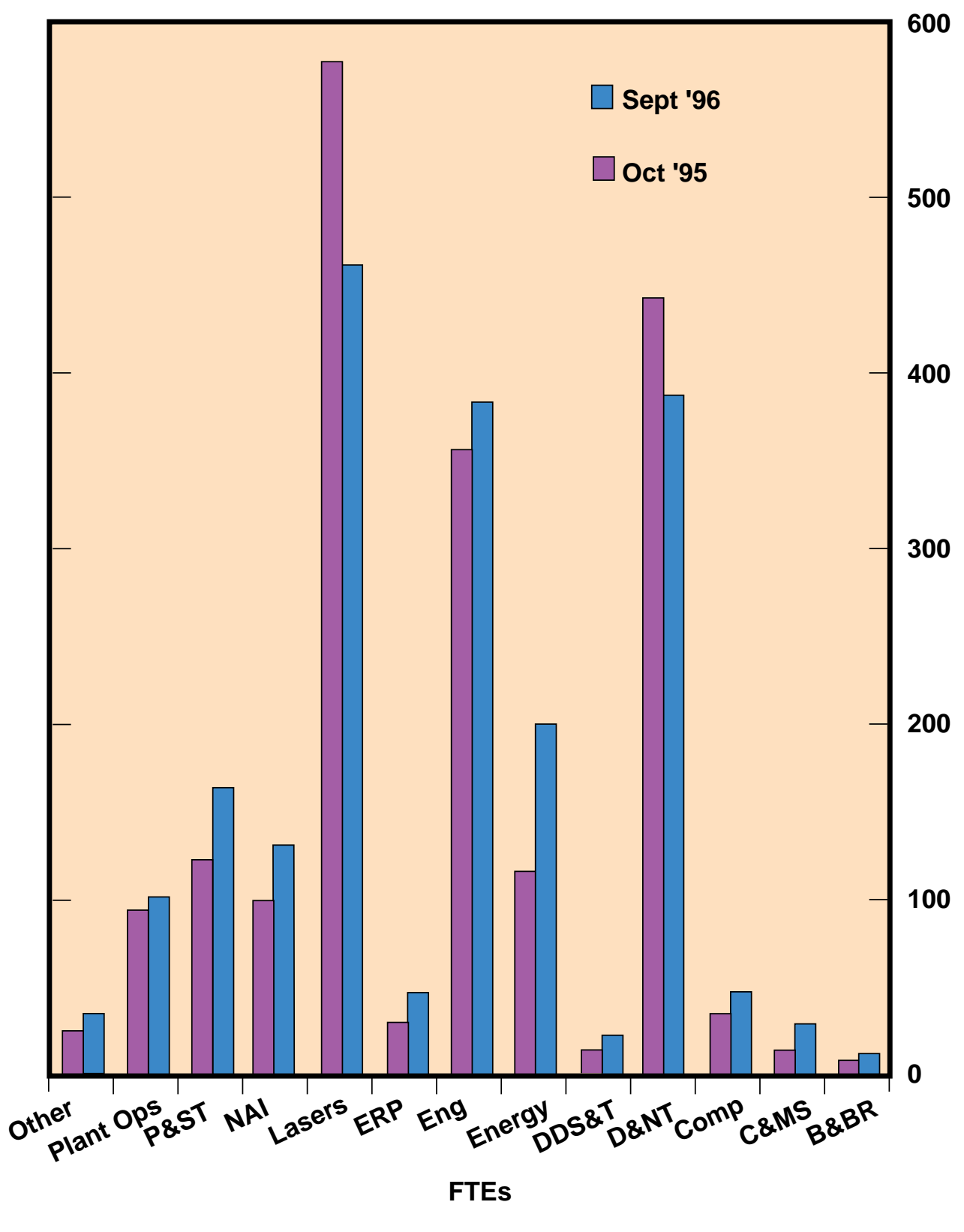




\section{FY96 Significant Accomplishments}

\section{Business Accomplishments}

\section{The Engineering Strategic Plan}

In 1996 we completed our strategic plan. Foremost in the plan is our commitment to our mission of "making programs succeed" and in recognizing that this is to be achieved by developing people and cutting-edge technologies. Recognizing that in the short-run we manage the flow of people and in the long-run the flow of technologies, many of our actions this year were directed toward improving how we strategically position and manage these processes. Also key to our plan is the recognition that what makes Engineering different is our core technology portfolio and the people who create and apply those technologies. In formulating our strategic plan, we re-examined the way our technology thrust areas (primary areas in which we focus our resources) are structured so we can develop technologies that are unique (otherwise why choose us?), the best (otherwise they do not belong to a national laboratory), and relevant (meaning that an LLNL program has a need for them).

This plan, which was distributed to all Engineering employees, also emphasizes higher organizational agility and flexibility, and highlights many of the operational accomplishments we targeted this year to specifically meet this objective.

\section{Reduction of Overhead Rates and Distributed Costs}

FY96 marked a continuation of Engineering's effort to reduce overhead rates. Spurred by the Cost Cutting Initiative (CCI) Program, which identified potential areas of cost reduction, and Engineering's plan to address its cost structure more aggressively, organizational personnel charges (OPC) were reduced from more than 23\% in FY95 to less than 20\% in FY96. Plans for FY97 call for additional OPC reductions to less than $17 \%$. These reductions, which are being implemented without further reducing education, training, and technology investments, can be directly attributed to Engineering's new mission, which correlates the importance of developing people and technology with our ability to make programs succeed. In addition to OPC, other Engineering overheads were also reduced.

\section{Consolidated Facilities}

In 1996 Engineering adopted a strategy of investing some of its General \& Administrative (G\&A) budget allocation to consolidating capabilities rather 
LLNL's acousticemission feedback loop enables precision grinding of optics.

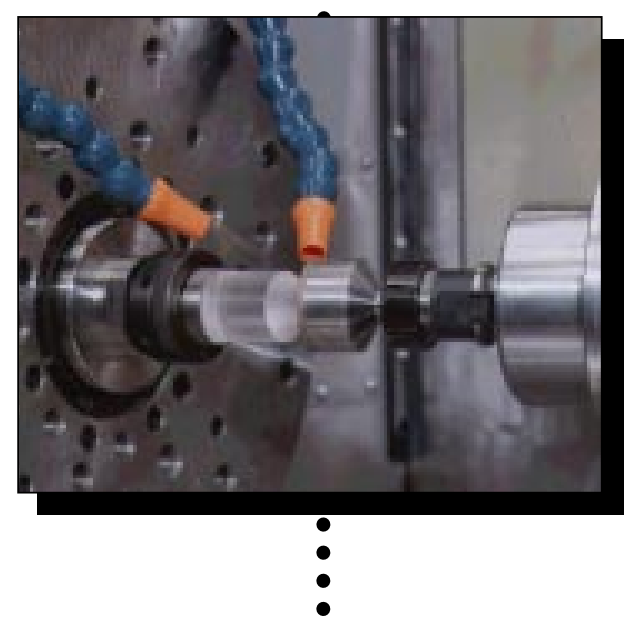

than just subsidizing facilities and services. We reduced our facility size from 880,000 gross square feet to 800,000 gross square feet - a net floor-space reduction of $10 \%$. From this, 53,000 gross square feet represent facilities excessed or returned to the institution, and 35,000 gross square feet represent transfer of facilities to the Chemistry \& Materials Science Directorate at Site 300 .

Notable among the facilities consolidated was the high-pressure laboratory, which was reduced to about $10 \%$ of its original size - without significant reduction in the spectrum of capabilities provided to its customers.

For Engineering, the overall space reductions achieved in FY96 should represent a net saving of $\$ 750,000$, which will enable us to invest in a highbandwidth communications infrastructure for our main Engineering facility (Building 131) as well as to reduce our facility overhead rates by an additional $8 \%$. These reductions are part of an integrated strategy to improve our operating leverage and thus enhance our future flexibility.

\section{Workforce Restructuring and Workforce Transfers}

Spurred by our plan to gain flexibility and better position Engineering for future programmatic success, we started unrolling a plan to restructure our workforce. In 1996, 7\% of the Engineering workforce participated in a Voluntary Separation Incentive Program (VSIP).

In spite of losing a rather significant portion of our workforce, we provided good support to all our customers. In order to do this, we transferred personnel between projects as needs changed over the year. Overall, more than $26 \%$ of the Engineering workforce made some significant assignment change, as exemplified by transfers between Engineering divisions.

\section{Commenced Restructuring of Core Technologies}

Last year, recognizing that we wish to employ unique, relevant and cutting-edge technologies to differentiate Engineering from other organizations, we began a reorganization of our eight thrust areas. In addition, we established a ninth in optical engineering.

In 1996, thrust areas (that to some extent represent the areas of core technology emphasis for Engineering), were functionally asked to report to the entire Engineering organization through the Associate Director's office. The aims of this reorganization were: to emphasize the thrust areas' multi-directorate involvement; to underscore Engineering's accountability to the Laboratory as a whole; and to forge a better amalgamation of mechanical and electronics technologies in our key areas of research interest. 


\section{Technical Accomplishments}

\section{National Ignition Facility (NIF) Final Title I Design Review}

The NIF Project engineering team completed documentation and formal presentations in support of the final Title I design review. Presentations in November were divided into four groups.

Group 1 included the support structures, spatial filters, beam enclosures, and the pulse generation system.

Group 2 included the laser control and alignment systems, and the target area systems.

Group 3 included power conditioning, pockels cell, the main amplifiers, and the final optics systems.

Group 4 included operations engineering and activation planning. Separate independent review committees were established for each of the groups.

All four review committees have submitted preliminary recommendations to accept the Title I designs and to proceed with Title II activities. The formal DOE approval to begin Title II was granted for the Group 1 systems on November 19. Approval for the other groups has also been received.

\section{Laser Cutting}

The Laser Cutting Project successfully demonstrated laser cutting technology using a 4 watt, 1 kilohertz, 180 femtosecond $\left(10^{-15}\right.$ second) pulsed laser. The demonstration showed the capability to cut a very narrow kerf in a variety of materials at cutting speeds required for the targeted applications. The demonstrated cuts were under 100 micrometers wide.

Personnel in Electronics Engineering's Laser Engineering Division developed and deployed the pointing \& control system, which kept the laser on target for a duration of more than six hours. Also developed for this demonstration was a laser diagnostic system, which was used to assess detailed laser performance issues with the goal of improving overall reliability of the laser system.

General engineering support (fabrication, cables, assembly, etc.) ensured that the project met the initial milestones on time and on budget. This project was done with many other engineering organizations' contributions, which included:

-Silhouette diagnostics, used to monitor the cutting in real time (Defense Sciences Engineering Division).

-Acoustic sensors, used to locate the initial position of the cut. Once determined, this position was then transferred to the laser pointing \& control system (Manufacturing and Materials Engineering Division).

-Positioning equipment, used to very accurately position the piece being 


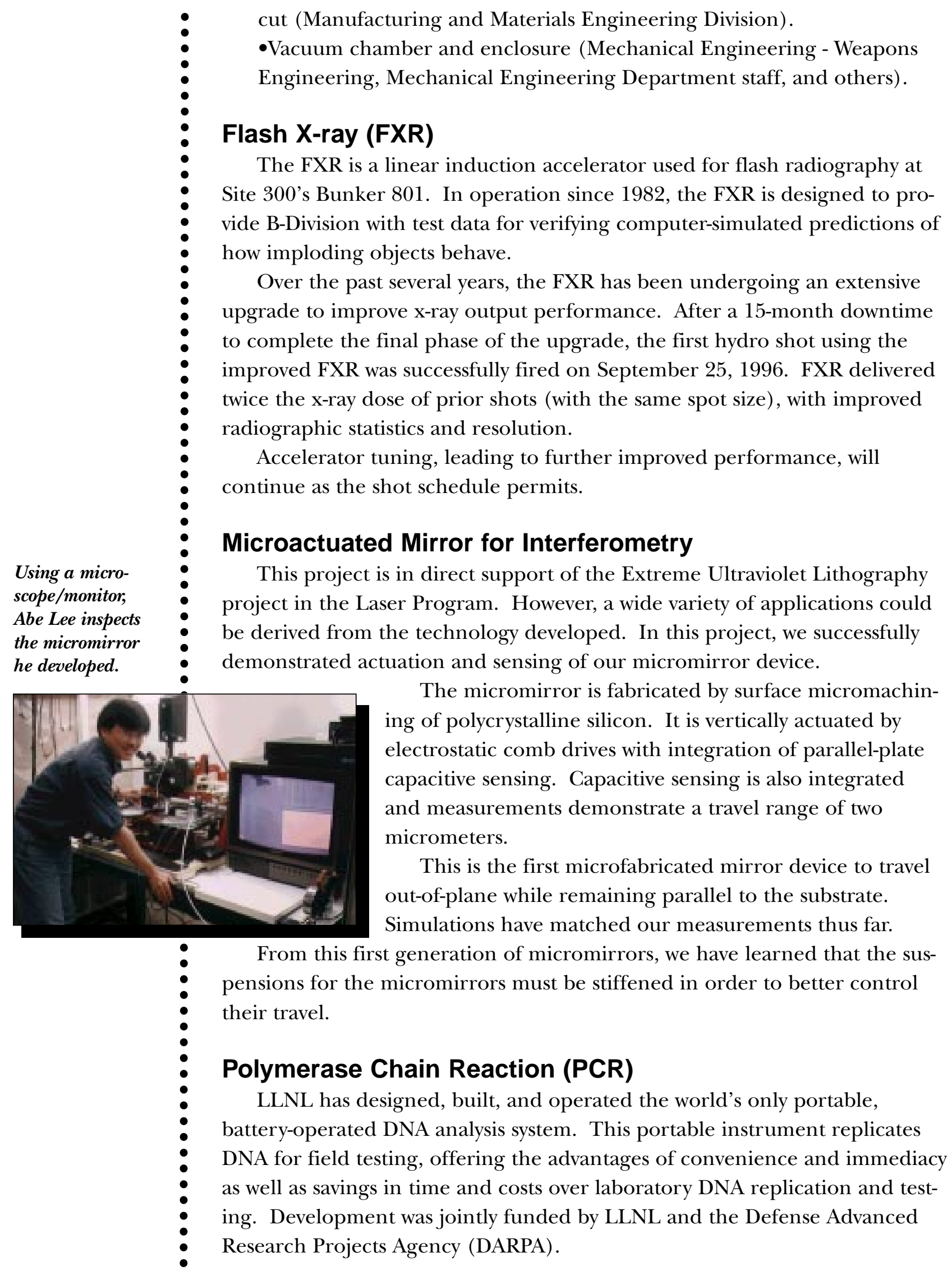


This instrument performs real-time detection of the product of the polymerase chain reaction (PCR) using the Taqman complementary DNA probe, invented by Roche Molecular Systems. One version of this instrument has been delivered to the Armed Forces Institute of Pathology. Another version is being used by LLNL personnel to detect surrogates of bio-warfare agents at Dugway, Utah, for the Joint Field Trials III.

This portable system has received a wide range of media attention, including features on CNN, San Francisco's Channel 4, and Livermore's local cable station as well as articles in the Los Angeles Times, New York Times, Valley Times, Stockton Record, and Tri-Valley Herald.

\section{Big Explosives Experimental Facility (BEEF)}

The Big Explosives Experimental Facility (BEEF) was built at the Nevada Test Site (NTS) to facilitate very large high explosives (HE) detonations with an array of sophisticated diagnostics, some of which require the presence of an operator.

The detonation of large HE charges in the proximity of a staffed experimental facility is unique. The facility's location makes it available for multiple users.

The original design criteria were specified for B-Division's Shaped-Charge Scaling Project in March, 1994. The site was selected based on these criteria, and New Technologies Engineering Division (NTED) completed the project from engineering design, through licensing, construction, testing, and documentation.

The POPOVER series of HE experiments certified the facility as safe for staffed operation with explosive charges of up to 5000 pounds of TNT under the existing license. The use of larger explosives is possible in the future. A Review Panel evaluated the POPOVER series. A Management Prestart Review was recently conducted by B-Division for BEEF.

\section{National Transparent Optical Network (NTON)}

The Advanced Telecommunications Program (ATP) is integrating the National Transparent Optical Network (NTON), a 10 gigabyte-per-second wavelength division multiplexed (WDM) network ringing the San Francisco Bay Area.

The ATP showcased the NTON at the Supercomputing '96 Conference in Pittsburgh on November 18-21, 1996.

Engineering established Internet access to the NTON network management system, optical switches, and optical spectrum analyzers through a recently implemented firewall that allowed us to display real-time network status information on the SC96 show floor. 

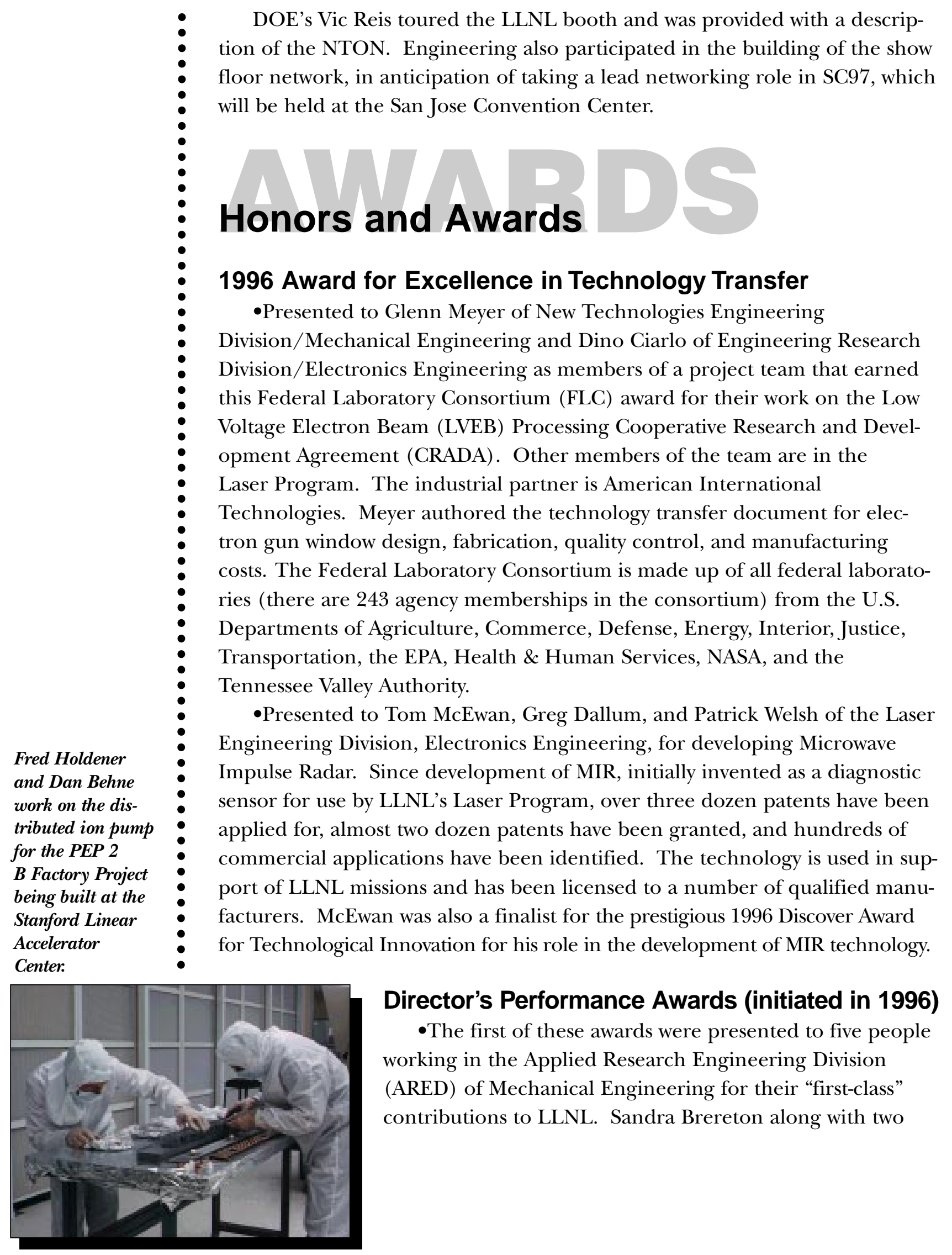

Director's Performance Awards (initiated in 1996)

-The first of these awards were presented to five people working in the Applied Research Engineering Division (ARED) of Mechanical Engineering for their "first-class" contributions to LLNL. Sandra Brereton along with two 
other team members received her award for "exceptional effectiveness in defining and defending the National Ignition Facility (NIF) environmental safety \& health (ES\&H) position. The team of Curt Belser, Lou Bertolini, Fred Holdener and Bob Yamamoto, along with two physicists from the Physics \& Space Technology Directorate, received their awards for "extending Livermore's technical mandate in the B Factory Project to establish the Laboratory as a major partner in a new arena."

\section{R\&D 100 Awards}

-Presented to Benjamin Law of the Engineering Research Division, Electronics Engineering, and other members of the team that developed the ultra-high density magnetic sensor. Teaming up with Read-Rite Corporation of Fremont, CA, and Laboratory scientists from the Advanced Microtechnology Program of the Laser Directorate, Law helped to develop this new sensor for reading computer hard disks that could allow storage of 100 to 200 times more information. Current computer hard disks store about 500 million to 1 billion bits of information per square inch. The new sensor should permit about 100 billion bits of information to be stored per square inch.

-Presented to Tom McEwan of the Laser Engineering Division, Electronics Engineering, for the Micropower Impulse Radar (MIR) electronic dipstick. The electronic dipstick senses the level of fluid or other material stored in tanks, vats, and silos, and also can be used in automobiles to read levels of a variety of fluids, including gasoline, oil, transmission fluid, coolant, and windshield washer fluid. MIR was invented as a diagnostic sensor for use by LLNL's Laser Program. The system's electronics are based on lowcost components that fit on a small circuit board.

-Presented to Sol Dijaili and Jeff Walker of the Engineering Research Division of Electronics Engineering for their work with the Physics \& Space Technology Directorate to develop a miniature, low-cost optical amplifier. This dime-sized semiconductor optoelectronic device is designed to amplify optical signals at ultra-high (terabit per second) rates, which is essential in fiberoptic communication systems. Potential applications include wide-area and local-area information networks, cable TV distribution, and computer interconnects. Research was funded under Laboratory Directed Research and Development (LDRD) and was conducted by members of Engineering's MicroTechnology Center.

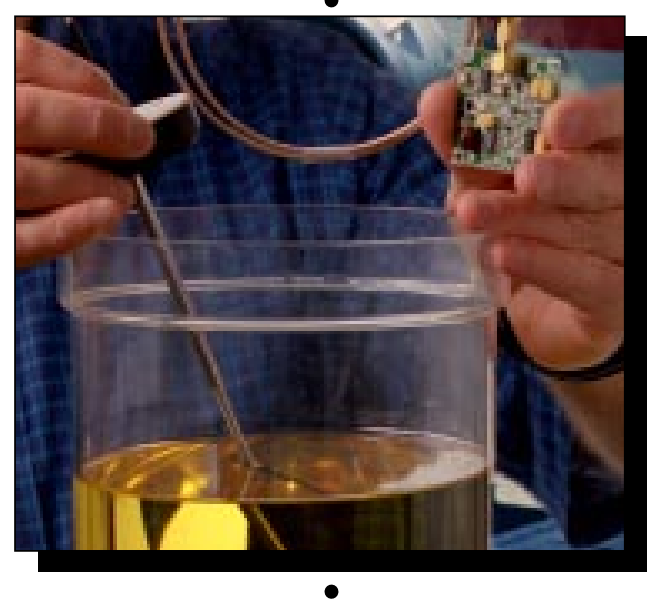

MIR electronic dipstick revolutionizes fluid measurement systems. 


\section{: Challenges for the Future}

The present report summarizes our accomplishments this last year. In the coming year, our key challenges are:

-To deliver on stretch projects that have an important bearing on the Laboratory's future (such as AVLIS, SSMP and NIF).

-To become increasingly vigilant about conducting our work in a safe manner.

- To begin to build a much stronger national professional reputation for Engineering; and to take the first steps to sharply improve ourselves. This last challenge requires us to seek opportunities in which the Laboratory can make significant contributions and then focus our technology investments commensurably. It also requires us to exploit the hiring opportunities recently created by expanding programs to attract exceptional new talent into Engineering.

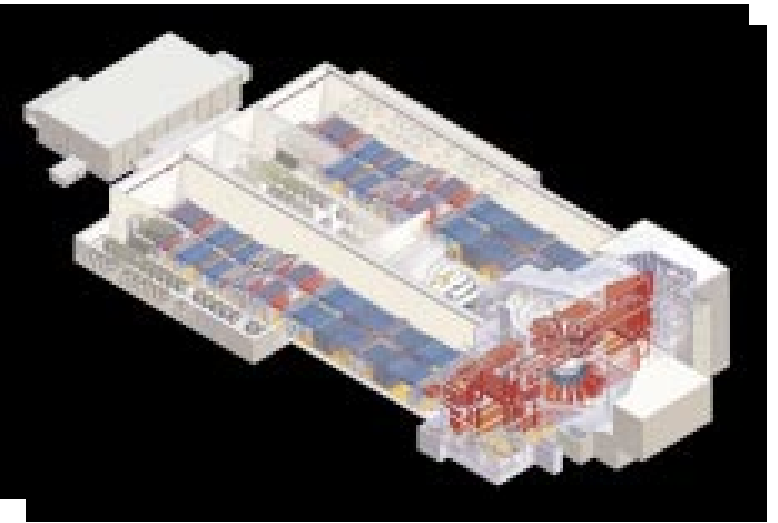

Left: The planned National Ignition Facility (NIF)

Lower left: Advanced Hydrotest Facility fast beam kicker

Lower right: Building 153, Electronics Engineering Microtechnology Center planned expansion
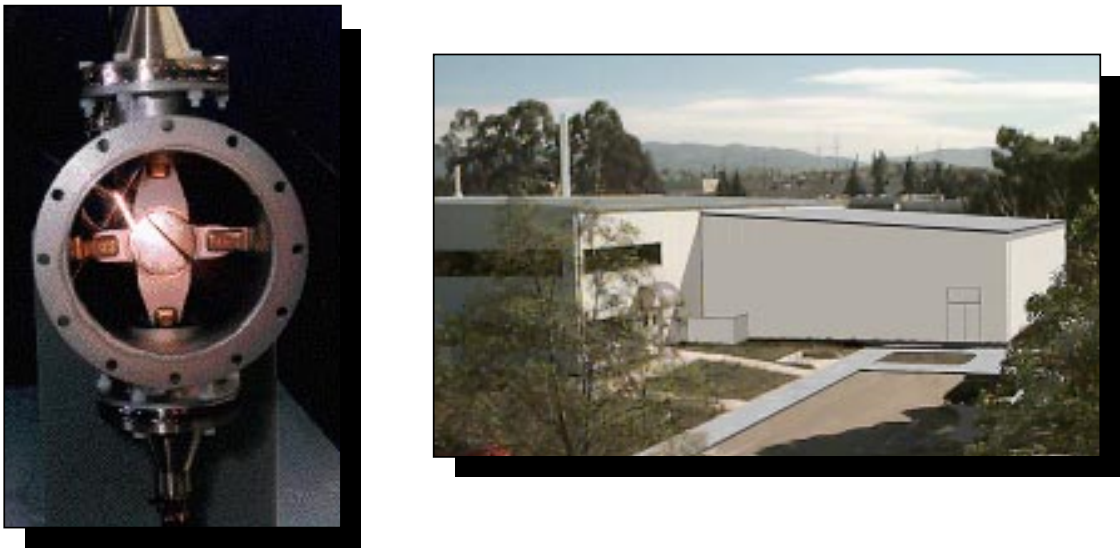


\section{Appendix}
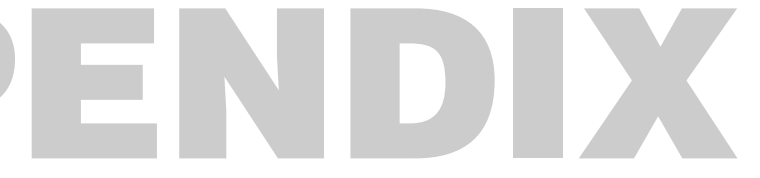

16 Engineering Costs by Budget Type

$16 \quad$ Engineering Five-Year Costing Trend

17 Engineering Department Organization Chart

18 LLNL Staffing and Education Levels

19 Engineering Workforce Changes

19 Engineering Staffing Profile

20 Engineering Facility Changes

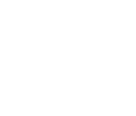




\section{Engineering Costs by Budget Type FY95-FY96}

(Excluding programmatic support)

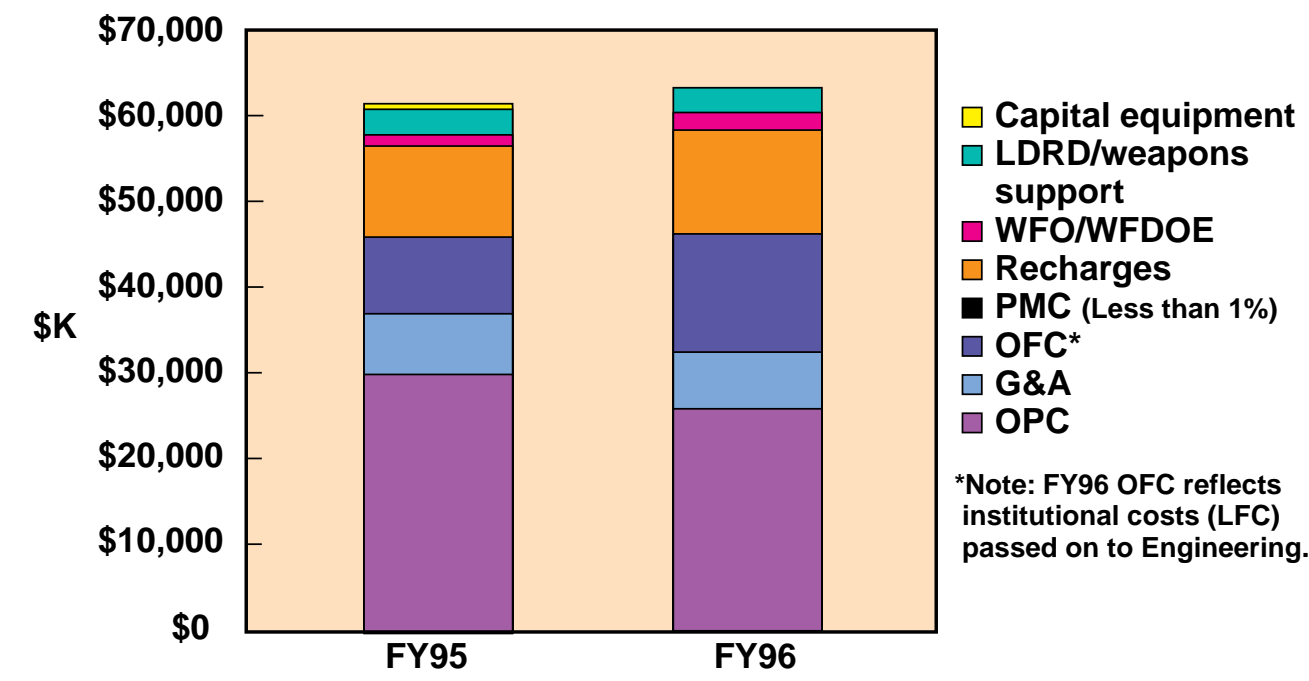

\section{Engineering Five-Year Costing Trend}

(Excluding programmatic support)

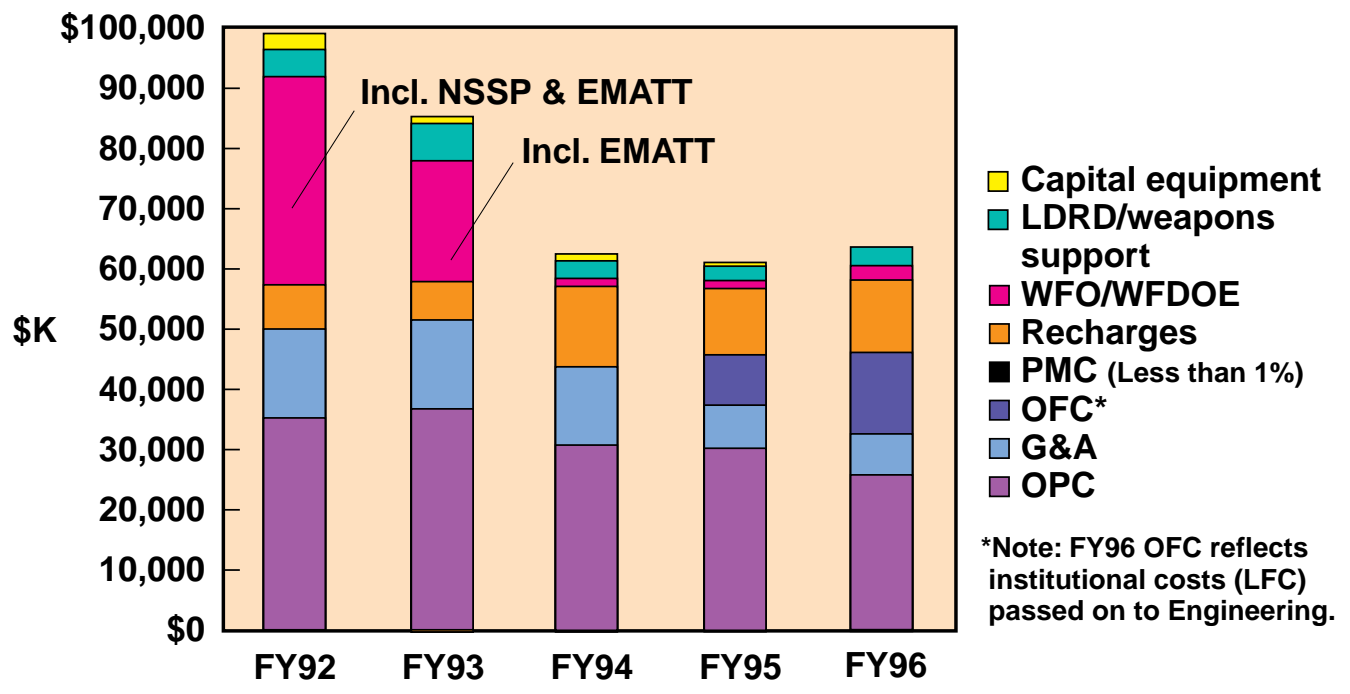




\section{Engineering Department Organization Chart 12/31/96}

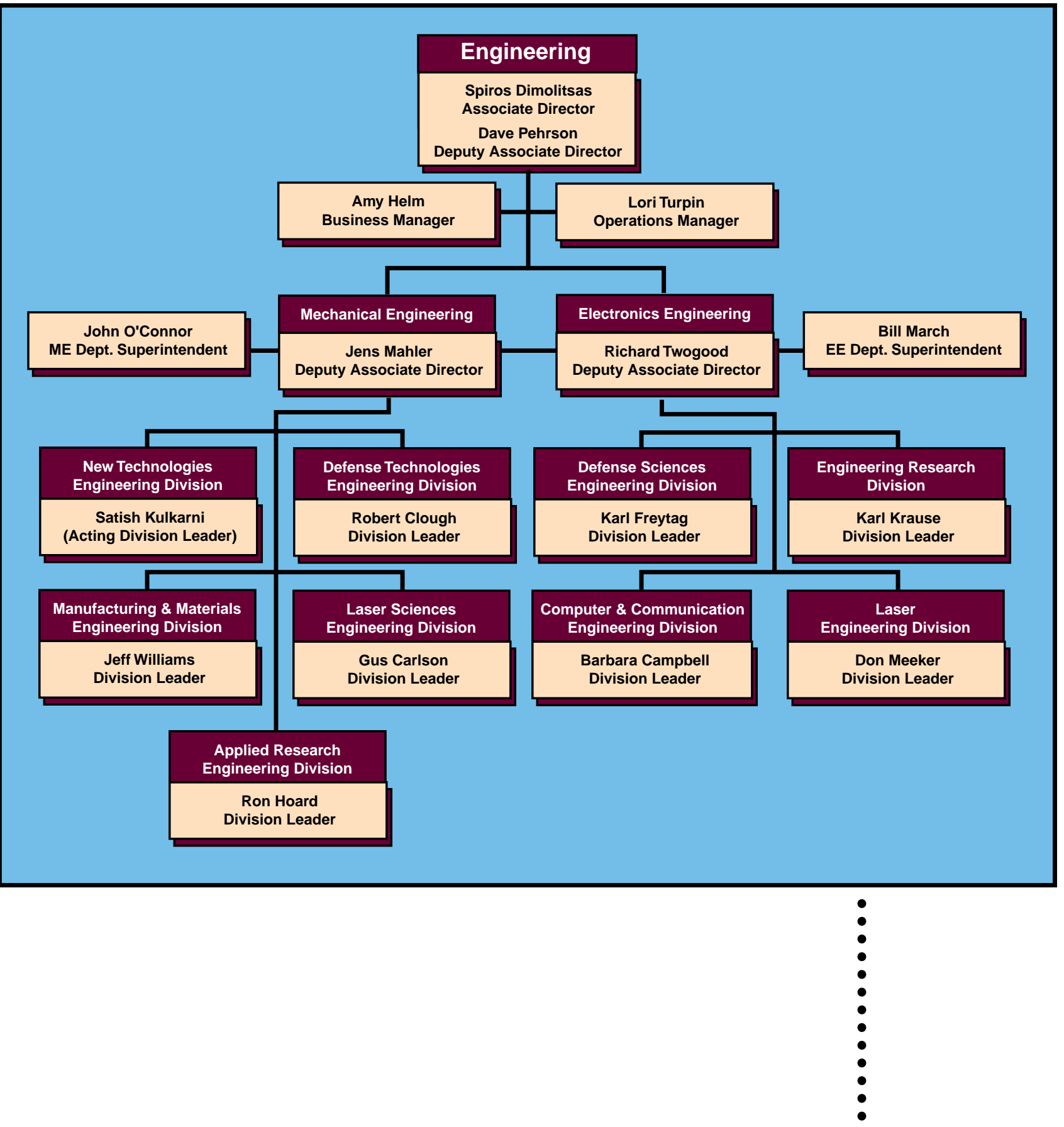




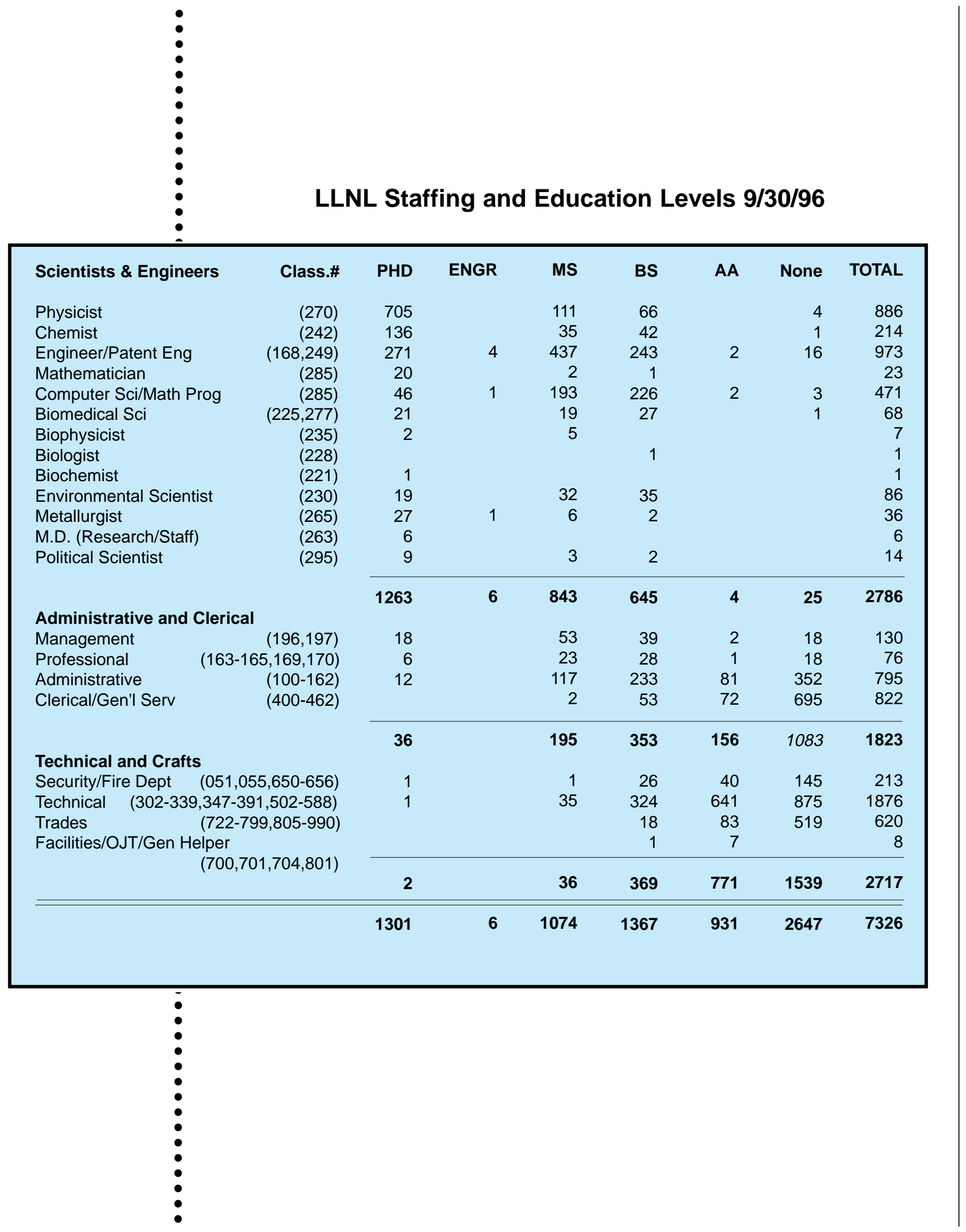


Engineering Staffing Profile 9/30/96

\begin{tabular}{|c|c|c|c|c|}
\hline & Total & Career & Term & $\begin{array}{l}\text { Other/ } \\
\text { Labor* }\end{array}$ \\
\hline $\begin{array}{l}100 \text { Series - Administration } \\
200 \text { Series - Engineers } \\
300 \text { Series - Supv/Associate } \\
400 \text { Series - Clerical } \\
500 \text { Series - Tech/Drafter } \\
700 \text { Series - Trainee } \\
900 \text { Series - Machinist }\end{array}$ & $\begin{array}{r}64 \\
742 \\
423 \\
132 \\
737 \\
11 \\
157\end{array}$ & $\begin{array}{r}60 \\
649 \\
408 \\
111 \\
710 \\
0 \\
157\end{array}$ & $\begin{array}{r}2 \\
70 \\
10 \\
14 \\
24 \\
0 \\
0\end{array}$ & $\begin{array}{r}2 \\
23 \\
5 \\
7 \\
3 \\
11 \\
0\end{array}$ \\
\hline Total & 2,266 & 2,095 & 120 & 51 \\
\hline
\end{tabular}

*Note: Other labor includes indeterminates and retirees.

\section{Engineering Workforce Changes FY96}

\begin{tabular}{|c|c|c|c|c|c|c|c|c|c|c|}
\hline & \multicolumn{2}{|c|}{$\begin{array}{c}\text { External Hires } \\
\text { Non- } \\
\text { Career Career }\end{array}$} & \multicolumn{2}{|c|}{\begin{tabular}{c}
\multicolumn{2}{c}{ Transfers In } \\
Non- \\
Career Career \\
\end{tabular}} & \multicolumn{2}{|c|}{$\begin{array}{c}\text { Terminations } \\
\text { Non- } \\
\text { Career Career }\end{array}$} & \multicolumn{2}{|c|}{$\begin{array}{l}\text { Retired } \\
\text { Non- } \\
\text { Career Career }\end{array}$} & \multicolumn{2}{|c|}{$\begin{array}{l}\text { Transfers Out } \\
\text { Non- } \\
\text { Career Career }\end{array}$} \\
\hline $\begin{array}{l}100 \\
200 \\
300 \\
400 \\
500 \\
900 \\
700\end{array}$ & $\begin{array}{r}0 \\
12 \\
2 \\
0 \\
0 \\
0 \\
0\end{array}$ & $\begin{array}{r}0 \\
35 \\
12 \\
2 \\
32 \\
0 \\
6\end{array}$ & $\begin{array}{r}0 \\
15 \\
2 \\
4 \\
2 \\
3 \\
0\end{array}$ & $\begin{array}{l}0 \\
4 \\
0 \\
0 \\
0 \\
0 \\
0\end{array}$ & $\begin{array}{r}2 \\
18 \\
7 \\
3 \\
33 \\
8 \\
0\end{array}$ & $\begin{array}{r}1 \\
35 \\
9 \\
3 \\
15 \\
1 \\
0\end{array}$ & $\begin{array}{r}0 \\
22 \\
29 \\
0 \\
14 \\
3 \\
0\end{array}$ & $\begin{array}{l}0 \\
0 \\
0 \\
0 \\
0 \\
0 \\
0\end{array}$ & $\begin{array}{r}20 \\
10 \\
3 \\
28 \\
8 \\
0 \\
0\end{array}$ & $\begin{array}{l}2 \\
5 \\
1 \\
2 \\
1 \\
0 \\
0\end{array}$ \\
\hline $\begin{array}{l}\text { Total } \\
\text { Heads }\end{array}$ & 14 & 87 & 26 & 4 & 71 & 64 & 68 & 0 & 69 & 11 \\
\hline Jote: Non & areers ar & indeterm & inate, fix & d-term/te & mps, sum & mers anc & retirees. & & $\begin{array}{l}\bullet \\
\bullet \\
\bullet \\
\bullet\end{array}$ & \\
\hline
\end{tabular}




\section{Engineering Facility Changes FY96}

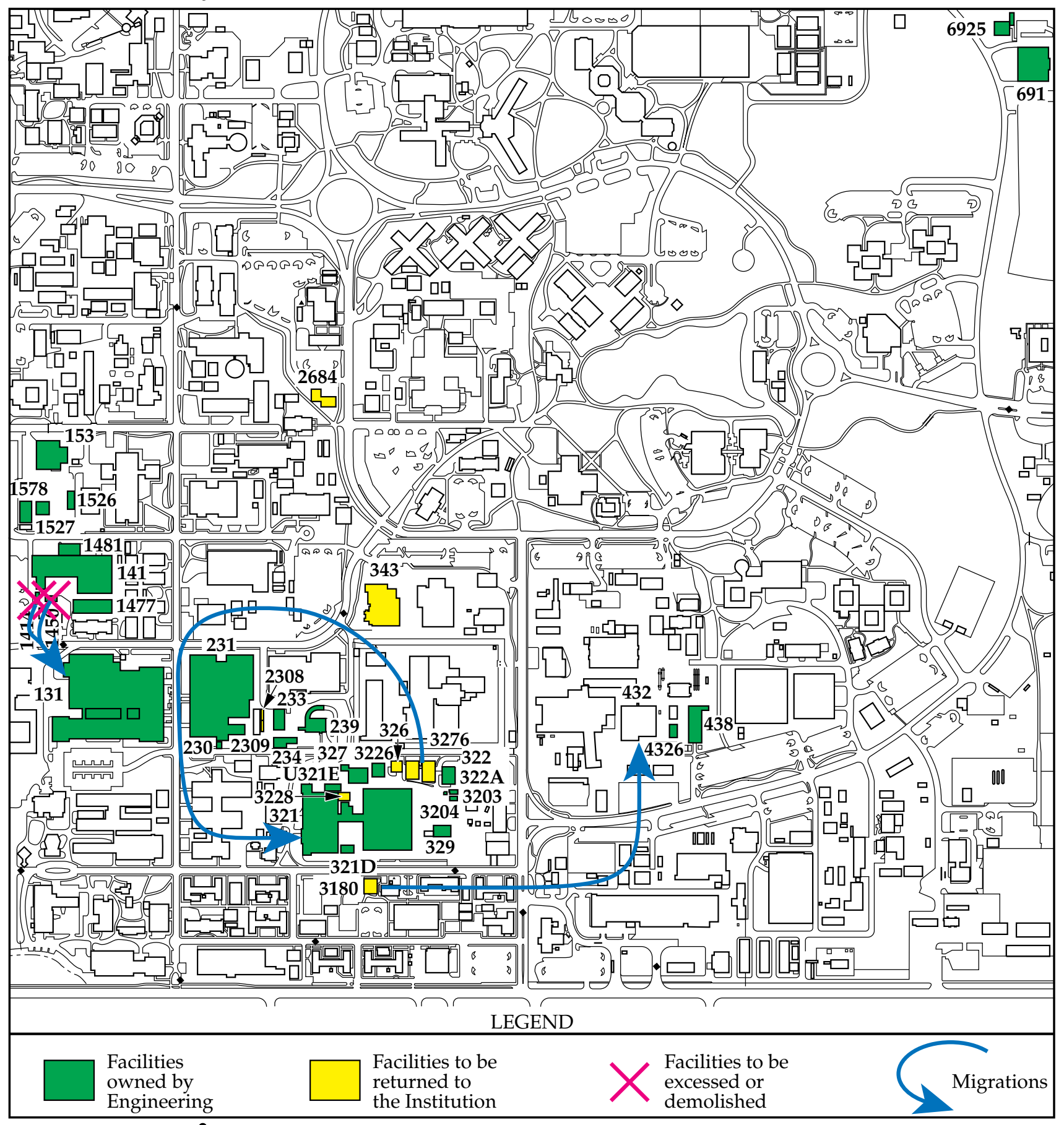




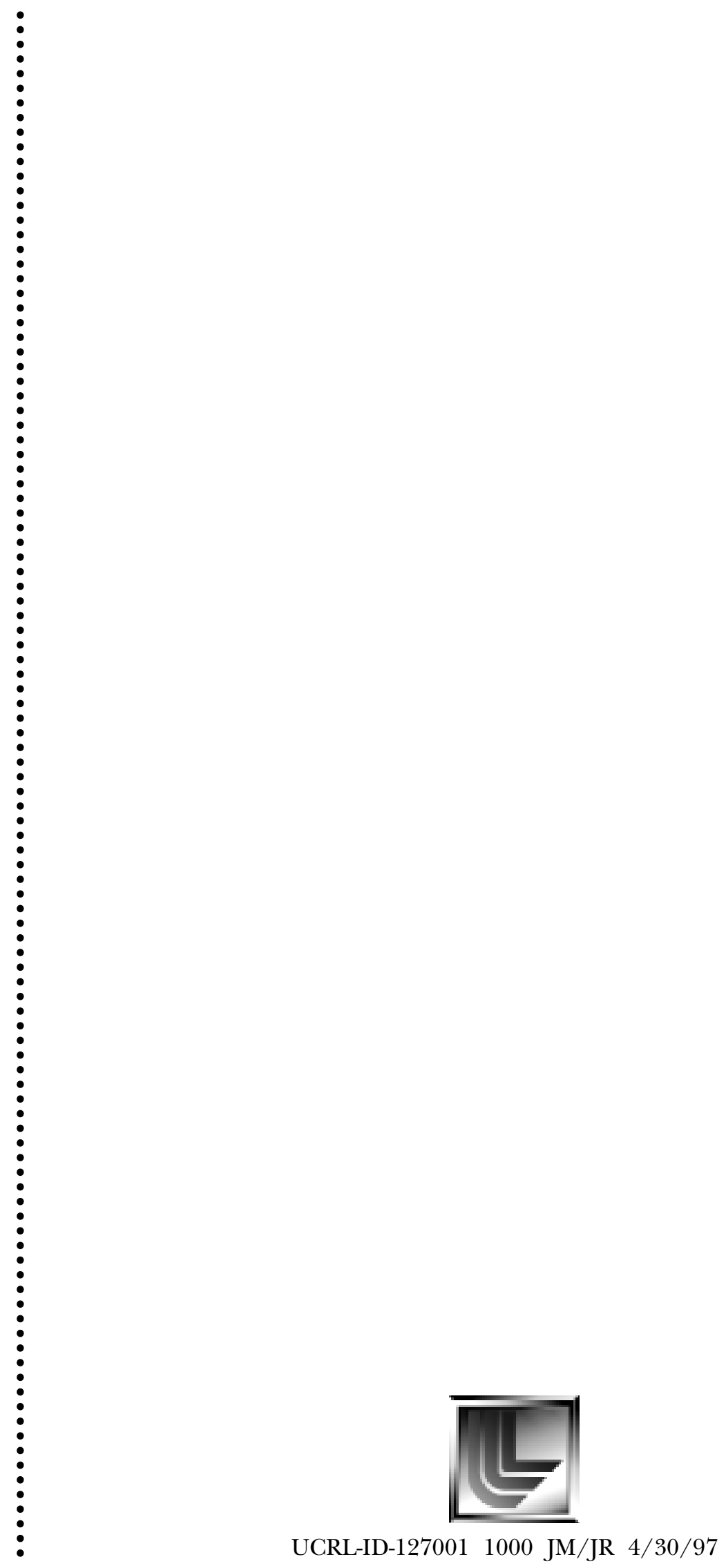

Engineering Annual Summary FY96 